\title{
ANNOUNCEMENTS
}

The 158th meeting of the

\section{PATHOLOGICAL SOCIETY OF GREAT BRITAIN AND IRELAND will be held at UNIVERSITY COLLEGE HOSPITAL, LONDON on January 4th, 5th and 6th, 1989}

Microbiology Programme (provisional)

Wednesday, January 5th a.m. Symposium-Nutrition and infection

Epidemiology and clinical aspects; malnutrition and immune and inflammatory responses; parenteral nutrition; antibiotic usage and animal nutrition.

p.m. Free papers and posters.

Thursday, January 6th a.m. Symposium-Mycobacterial infection

The current situation in the UK; mycobacteria and the immune response; mycobacteria and AIDS; infections of animals.

p.m. Free papers and posters.

Further information may be obtained from the Meetings Secretary:

Professor E. Mary Cooke, Central Public Health Laboratory, Division of Hospital Infection, 61 Colindale Avenue, London NW9 5HT.

Tel: 01-200 4400 Ext 4249.

\section{TECHNIQUES \& APPLICATIONS OF MOLECULAR BIOLOGY:}

A COURSE FOR MEDICAL PRACTITIONERS

University of Warwick, UK, 12-14 December 1988

Further information is available from:

Dr Rachel Strachan,

Department of Biological Sciences, University of Warwick, Coventry CV4 7AL, UK

\section{CURRENT MEDICAL LITERATURE-INFECTIOUS DISEASES}

Glaxo Laboratories Ltd are sponsoring a number of subscriptions to this journal which they wish to make available to readers of the Journal of Medical Microbiology. The publication is intended to provide its readers with a manageable source of information on current developments, advances and controversies selected from a comprehensive scanning of the international literature. It is published by Current Medical Literature Ltd in conjunction with the Royal Society of Medicine. If you are interested in this offer please contact Dr E Rawlinson, Current Medical Literature Ltd, 40-42 Osnaburgh Street, London NW1 3ND. 


\section{BOOKS RECEIVED}

\section{Bacterial Cell Surface Techniques}

Edited by I. C. HANCocK and I. R. Poxton. 1988. John Wiley and Sons, Chichester. Pp. XV and 329. £40.00.

This book, which contains contributions from a number of experts, describes current technology for the isolation, purification and analysis of components of the bacterial cell surface. It is essentially a laboratory manual, but one which contains a very good description of the theoretical background to the techniques employed. The book includes chapters on the structure of bacterial envelopes, culture techniques, the isolation and purification of cell walls, separation and purification of surface components, chemical analysis of envelope polymers, immunochemistry of cell surfaces, applications (e.g., vaccines and immunological tests) and general methods. It will be of interest to those concerned with the basis of bacterial pathogenicity, diagnosis and identification. Despite having numerous contributors the book is well written, free of errors and is of even style. Experimental protocols are clearly written and would be easy to follow in the laboratory. A very useful international directory of suppliers of specialist reagents and equipment is provided as an appendix. There is a good clear set of figures and photographs which not only help in conveying theoretical points but give the reader an idea of the form in which data may be extracted from the methods. This book contains a body of information which to my knowledge has not previously been gathered together in one convenient source. It is an essential purchase for any laboratory that has an interest in the bacterial cell surface.

J. R. SAUNDERS

\section{Anaerobic infections}

By A. T. Willis and K. D. Phillips. 1988. PHLS Supplies, London. Pp. vii and 162. £20.00.

This book is a greatly extended version of the PHLS Monograph on the same subject, with contributions from two further authors covering clostridial food poisoning and Clostridium difficile antibiotic-associated diarrhoea and colitis. Consideration given in early chapters to the range of anaerobic infections and natural habitats of the causative organisms encountered in clinical practice provides a useful backcloth to subsequent descriptions of methods of diagnosis, culture and identification. Considerable attention is given to the practical problems that beset microbiologists in dealing with anaerobic infections both at the bedside and in the laboratory. This is an easily read book with virtually no textual errors and the style conveys the feeling that the authors know their business at first hand. Highly recommended.

H. R. INGHAM 